\title{
Malignancy and the Small-intestinal Mucosa
}

\author{
B. CREAMER,* M.D., M.R.C.P.
}

Brit. med. F., 1964, 2, 1435-1436

The observations presented here suggest that malignancy anywhere in the body may be accompanied by a secondary change in the small-intestinal mucosa, including the flattened appearance that is usually seen in idiopathic steatorrhoea. The reverse of this association, that idiopathic steatorrhoea may be complicated by a reticulosis, has been reported by Gough et al . (1962). They described four cases and collected 16 other reports from the literature where the timing of events supported the view that the steatorrhoea was primary and the reticulosis secondary.

\section{Materials and Methods}

Nine specimens of small-intestinal mucosa were available for examination; eight were jejunal and one was ileal. In six cases the primary growth was outside the gastro-intestinal

\begin{tabular}{|c|c|c|c|c|c|c|c|}
\hline $\begin{array}{l}\text { Case } \\
\text { No. }\end{array}$ & $\begin{array}{l}\text { Sex } \\
\text { and } \\
\text { Age }\end{array}$ & Site & $\begin{array}{c}\text { Weight } \\
\text { Loss }\end{array}$ & $\begin{array}{c}\text { Faecal } \\
\text { Fats } \\
\text { (g./24 hr.) }\end{array}$ & $\begin{array}{l}\text { Serum } \\
\text { Iron } \\
(\mu \text { g. })\end{array}$ & $\mid \begin{array}{c}\text { Serum } \\
\text { Vit. } B_{12} \\
(\mu \mu \mathrm{g} .)\end{array}$ & Remarks \\
\hline $\begin{array}{l}1 \\
2\end{array}$ & $\begin{array}{ll}M & 58 \\
\text { F } 61\end{array}$ & $\begin{array}{l}\text { Bronchus } \\
\text { Bile-duct }\end{array}$ & $\begin{array}{l}\text { Nil } \\
\text { Slight }\end{array}$ & $\begin{array}{r}5 \cdot 1 \\
20 \cdot 3\end{array}$ & 85 & & \multirow{4}{*}{$\begin{array}{l}\text { Obstructive } \\
\text { jaundice } \\
\text { Exudative } \\
\text { enteropathy } \\
\text { Xylose excretion } \\
3.1 \mathrm{~g} \text {. in } 5 \mathrm{hr} \text {. }\end{array}$} \\
\hline $\begin{array}{l}3 \\
4 \\
5\end{array}$ & $\begin{array}{ll}\mathrm{P} & 68 \\
\mathrm{M} & 59 \\
\mathrm{~F} & 75\end{array}$ & $\begin{array}{l}\text { Caecum } \\
\text { Bronchus } \\
\text { Stomach }\end{array}$ & $\begin{array}{l}\text { Nil } \\
2 \text { st. } \\
3 \text {;" }\end{array}$ & $\overline{10 \cdot 0}$ & $\overline{13}$ & $\overline{90}$ & \\
\hline 6 & F 50 & Ovary & $\mathrm{Nil}$ & $9 \cdot 4$ & - & - & \\
\hline $\begin{array}{l}7 \\
8 \\
9\end{array}$ & $\begin{array}{ll}\mathrm{F} & 42 \\
\mathrm{P} & 40 \\
\mathrm{P} & 67\end{array}$ & $\begin{array}{l}\text { Adrenal } \\
\text { Cervix } \\
\text { Small } \\
\text { intestine }\end{array}$ & $\begin{array}{l}\frac{1}{1 \text { st. }} \\
2 \% ” \\
2 \%\end{array}$ & $\begin{array}{l}15 \cdot 3 \\
1.8 \\
26.0\end{array}$ & $\overline{45}$ & $\begin{array}{l}360 \\
75 \\
700\end{array}$ & \\
\hline
\end{tabular}

tract, while in the gut one was a carcinoma of the stomach, one a carcinoma of the caecum, and the third had multiple amall-intestinal polyps of which many were malignant (Table I). Five specimens were surgical and four were obtained perorally. The specimens were examined and cell counts made as previously described (Creamer, 1964).

* Consultant Physician, St. Thomas's Hospital, London.

\section{Results}

The findings are summarized in Table II. In three cases the mucusa appeared perfectly normal. Two of the specimens were jejunal and one was from the ileum. The villi were

\begin{tabular}{|c|c|c|c|c|c|c|}
\hline $\begin{array}{l}\text { Case } \\
\text { No. }\end{array}$ & $\begin{array}{c}\text { Mucosal } \\
\text { Appearance }\end{array}$ & $\begin{array}{c}\text { Mucosal } \\
\text { Height }(\mu)\end{array}$ & $\begin{array}{l}\text { Adult- : } \\
\text { Crypt-cell } \\
\text { Ratio }\end{array}$ & $\begin{array}{c}\text { Crypt } \\
\text { Length } \\
\text { (cells) }\end{array}$ & $\begin{array}{c}\text { Crypt } \\
\text { Mitotic } \\
\text { Rate (\%) }\end{array}$ & $\begin{array}{l}\text { Weight } \\
\text { Loss }\end{array}$ \\
\hline $\begin{array}{l}1 \\
2 \\
3 \\
4 \\
5 \\
6 \\
7 \\
8 \\
9\end{array}$ & $\begin{array}{l}\text { Normal } \\
\text { ", } \\
\text { Hypoplastic } \\
\text { Flat" } \\
\text { ", } \\
\text { ", }\end{array}$ & $\begin{array}{l}700 \\
850 \\
660 \\
350 \\
200 \\
350 \\
400 \\
300 \\
350\end{array}$ & $\begin{array}{rl}3 & \vdots 1 \\
3 & 1 \\
3 & \vdots 1 \\
2 \cdot 2 & \vdots 1 \\
1 \cdot 5 & 1 \\
1 & \vdots 2 \cdot 2 \\
1 & : 1 \cdot 7 \\
1 & : 1 \\
1 & : 2 \cdot 3\end{array}$ & $\begin{array}{l}27 \\
29 \\
27 \\
20 \\
20 \\
43 \\
45 \\
30 \\
44\end{array}$ & $\begin{array}{l}1.3 \\
1.0 \\
1.3 \\
0.2 \\
0.6 \\
0.9 \\
1.0 \\
0.9 \\
0.5\end{array}$ & $\begin{array}{l}\text { Nil } \\
\text { Slight } \\
\text { Nil } \\
2 \text { st. } \\
3 \text { Nil } \\
\text { Nil } \\
\text { t st. } \\
2 \text { "” } \\
2 \text { ", }\end{array}$ \\
\hline
\end{tabular}

finger-shaped and the ratio of adult cells to crypt cells and the mitotic rate were normal (Fig. A).

Two cases showed a hypoplastic pattern with a thin mucosa and short crypts with a low mitotic rate (Fig. B). The dissecting-microscope appearance revealed leaf-shaped villi, and in both cases the ratio of adult cells to crypt cells was low. In one of these cases (No. 5) two specimens were available. Both pieces showed the same pattern, but the mucosal height varied from about half the normal height in one to a quarter the normal height in the other.

The other four cases all had a grossly abnormal appearance with a flattened mucosal structure such as is typically seen in idiopathic steatorrhoea (Fig. C). The specimen from Case 7 was a surgical biopsy and the changes were diffuse and equalthis case was previously reported in a study on idiopathic steatorrhoea (Creamer, 1962). In Case 9, with multiple malignant polyps, a resection of intestine had been performed and a large area of mucosa was available. The mucosa was completely flat on the crests of the mucosal folds, but in the sheltered troughs some attempt at villous formation was apparent.

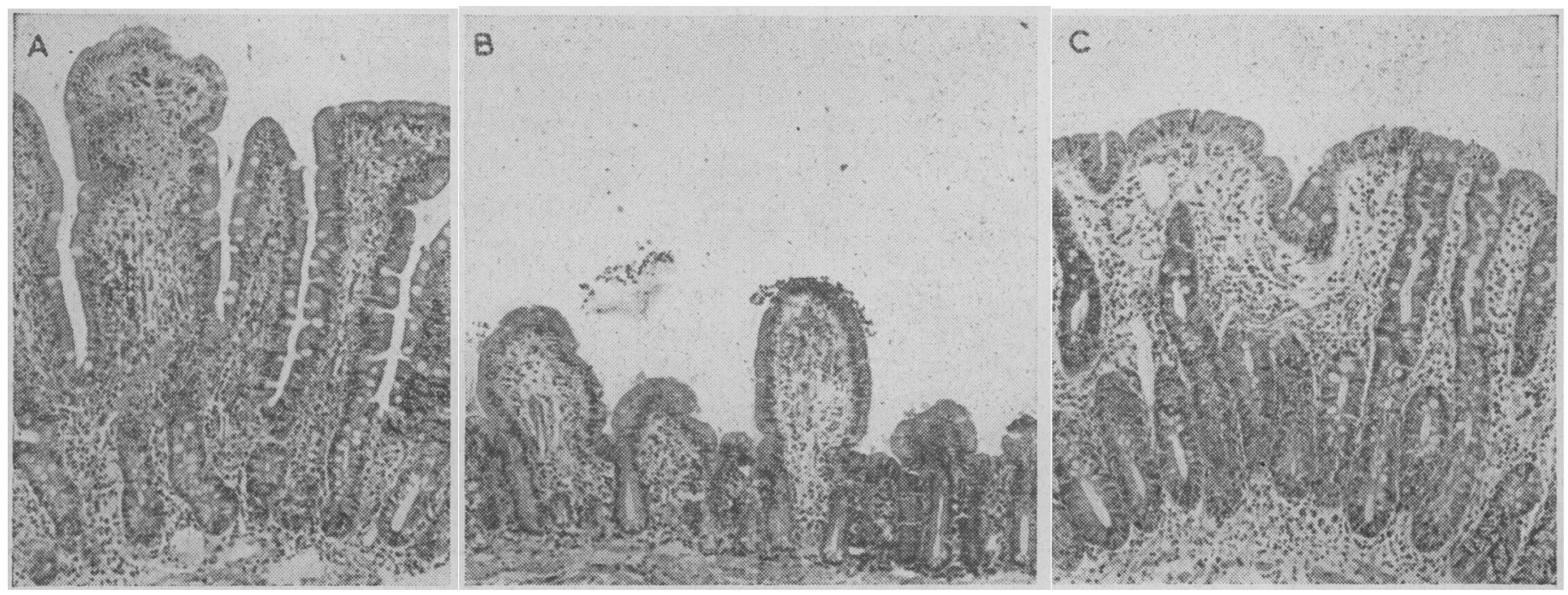

Photomicrographs of iejunal mucosa showing (A) normal appearance (Case 1), (B) hypoplastic appearance (Case 5), and (C) a flat mucosa (Case 7). 


\section{Clinical Correlation}

There seems to be no evidence that the site of the primary growth bears any relation to the condition of the smallintestinal mucosa. The clinical state of the patients does appear to relate to the mucosal structure (Tables I and II). Thus the three patients with a normal mucosal appearance were comparatively fit, and only one (Case 2) had slight loss of weight. This patient had obstructive jaundice from a carcinoma of the common bile-duct and steatorrhoea. Of the six patients with an abnormal mucosa five had lost weight and in four steatorrhoea was present.

\section{Discussion}

It would be wrong to generalize from such a selected series, but there is a strong suggestion that the small-intestinal mucosa can be secondarily affected by a malignant growth. Two patterns are seen, either a hypoplasia of the mucosa or a flattened mucosa similar to that found in idiopathic steatorrhoea and probably due to a maturation arrest of crypt cells (Creamer, 1962). It is possible that four patients had coincidental idiopathic steatorrhoea, but the odds would seem to be heavily against this. In only one of these cases had a gluten-free diet been tried, so far without response. Even if a response to gluten withdrawal were obtained the distinction between a primary and a secondary mucosal change would not necessarily be certain.

The clinical correlation is of considerable interest. It may well be that some of the ill-health and loss of weight in malignancy is caused by an abnormal small-intestinal mucosa. A similar picture has been reported in chronic ulcerative colitis by Salem et al. (1964).

\section{Summary}

The small-intestinal mucosa has been examined from nine cases with malignancy, of which six arose outside the gastrointestinal tract. In three cases the mucosa appeared normal and in six cases marked abnormalities were found, two showing a thin hypoplastic mucosa and four a flattened mucosa as in idiopathic steatorrhoea. Loss of weight and ill-health appeared to be associated with an abnormal small-intestinal mucosa.

I am grateful to Dr. G. C. J. Wiernik and Dr. A. B. Myles for assistance in obtaining two of the specimens.

\section{REFERENCES}

Creamer, B. (1962). Gut, 3, 295.

(1964). Brit. med. F., 2, 1371.

Gough, K. R., Read, A. E., and Naish, J. M. (1962). Gut, 3, 232.

Salem, S. N., Truelove, S. C., and Richards, W. C. D. (1964). Brit. med: f., 1, 394.

\title{
Haematoma of the Umbilical Cord
}

\author{
P. K. IRANI,* M.B., M.R.C.o.G.
}

Reported cases of haematoma of the umbilical cord associated with pregnancy are rare. Dippel (1940) reviewed the world literature and added a further eight cases of his own, bringing the total of such cases to 36 . Three further cases have since been reported-one each by Breen et al. (1958), Toland et al. (1959), and Kretowicz (1961). The rarity of this lesion has prompted the following case reports.

\section{Case 1}

A 25-year-old primigravida was admitted to hospital on 8 April 1964 five days past her expected date of confinement. Her prenatal course had been essentially normal, although at 35 weeks she had been treated for iron-deficiency anaemia with parenteral iron and folic acid. She was Wassermann- and rhesus-negative without antibodies.

Examination revealed a full-time intrauterine gestation; the foetus presented by the vertex and the head was not engaged; the foetal heart rate was 140 per minute. On vaginal examination the pelvis was adequate and the remainder of the physical examination was non-contributory.

On 14 April, during routine ward check-up, the foetal heart was discovered to have slowed to 78. During the few days prior to this, while she was in hospital, the foetal heart rate had been recorded as regular, varying from 130 to 140 . The patient was examined vaginally and the cord was not presenting. The membranes were ruptured and the liquor contained thick meconium; lower-segment caesarean section was therefore immediately performed. A swelling

- Senior Registrar, Royal Maternity Hospital, Belfast. At present Con-
sulting Obstetrician and Gynaecologist, Mission Hospital, Trichur, South India. of the cord extending for $10 \mathrm{~cm}$. from the umbilicus and $5 \mathrm{~cm}$. in diameter was found; it was dark red in appearance and was reminiscent of a gangrenous loop of bowel.

Gross examination of the placenta, which had been situated at the fundus, showed it to be essentially normal, $18 \mathrm{~cm}$. in diameter, and weighing $500 \mathrm{~g}$. The cord measured $40 \mathrm{~cm}$. and was attached to the placenta $5 \mathrm{~cm}$. from its edge. The contents of the swelling appeared to be clotted blood. No abnormalities of the remaining cord were identified.

On histological examination of multiple sections of the umbilical cord the umbilical arteries were normal ; the cord was distended by a haematoma of recent origin which was continuous at one point with the lumen of the vein. Pathologically the cause of rupture of this vessel could not be determined.

The infant, a male, weighed $5 \mathrm{lb} .12 \mathrm{oz}$. $(2,610 \mathrm{~g}$.). The cardiac rate at birth was 78 and persisted so for two days. E.C.G. and chest $x$-ray film showed no cardiac abnormality and there was sinus bradycardia. The baby's haemoglobin was $110 \%$. After a normal post-partum course both patient and infant were discharged from hospital.

\section{Case 2}

A primigravida aged 35, married 11 years, expected her first child on 18 March 1960 . The prenatal course was normal and she went into spontaneous labour on 31 March 1960. The foetal heart stopped suddenly in the first stage five and a half hours before delivery and she delivered a male stillborn infant with a swelling of the umbilical cord near the umbilicus.

Necropsy revealed no abnormality except that the cord contained a haematoma, $7 \mathrm{~cm}$. long and $6 \mathrm{~cm}$. in diameter, due to rupture of the umbilical vein, the aetiology of which could not be determined. The placenta was normal.

The patient has since had one normal infant. 